\title{
PERENCANAAN STRUKTUR DENGAN METODE DDBD BESERTA TINGKAT KINERJANYA DAN IDEALISASINYA TERHADAP SNI $1726: 2012$
}

\author{
Nikko Rianto ${ }^{1}$ dan Edison Leo ${ }^{2}$ \\ ${ }^{1}$ Program Studi Sarjana Teknik Sipil, Universitas Tarumanagara, Jl. Letjen S. Parman No.1 Jakarta \\ Email: nikko.rianto@gmail.com \\ ${ }^{2}$ Program Studi Sarjana Teknik Sipil, Universitas Tarumanagara, Jl. Letjen S. Parman No.1 Jakarta \\ Email: edisonl@ft.untar.ac.id
}

\begin{abstract}
ABSTRAK
Perencanaan struktur bangunan gedung tinggi terhadap beban gempa umumnya dilakukan pendekatan desain berbasis gaya. Dalam desain berbasis gaya, biasanya akan dihitung nilai gaya geser dasar desain untuk meramalkan berapa besar nilai gaya yang diberikan pada bangunan pada saat gempa terjadi. Sedangkan dalam desain berbasis kinerja, untuk meramalkan berapa besar gaya geser desain yang diberikan pada bangunan saat terjadi gempa untuk mencapai kinerja struktur yang diinginkan, salah satunya adalah metode Direct Displacement Based Design (DDBD) Priestley et.al. 2007. Dalam metode ini perpindahan sebagai dasar penentuan beban gempa. Desain dengan metode $D D B D$ diverifikasi apakah desain sudah sesuai dengan tingkat kinerja yang ingin dicapai dilakukan analisis pushover. Hasil dari analisis pushover berdasarkan pada prinsip desain balok lemah kolom kuat, sehingga sendi plastis tidak boleh terjadi pada kolom sebelum balok mengalami keruntuhan. Dari hasil analisis pushover akan didapatkan kurva kapasitas yang akan menjadi dasar penentuan tingkat kinerja dan sesuai dengan ATC-40, FEMA 356, dan FEMA 440. Kemudian kurva kapasitas tersebut diolah dengan pendekatan gaya untuk mendapatkan parameter-parameter respons struktur $\mathrm{R}, \Omega$, dan $\mathrm{Cd}$ dan dibandingkan dengan yang terdapat pada SNI 1726 : 2012. Tingkat kinerja struktur gedung yang didapat berada pada level Damage Control. Parameter respons struktur yang didapat lebih kecil daripada yang tercantum pada SNI $1726: 2012$.
\end{abstract}

Kata kunci: gaya geser dasar, analisis pushover, kurva kapasitas, tingkat kinerja, parameter respons struktur

\section{PENDAHULUAN}

\section{Latar Belakang}

Indonesia merupakan negara yang dikelilingi oleh tiga lempeng raksasa yaitu Lempeng Samudra Indo-Australia, Lempeng Eurasia dan Lempeng Samudra Pasifik. Oleh karena itu, Indonesia memiliki risiko yang tinggi terhadap beban gempa terhadap gempa bumi akibat interaksi antara ketiga lempeng tersebut. Dengan tingginya risiko terjadi gempa, maka tinggi pula risiko kerusakan pada bangunan. Sehingga perencanaan struktur gedung terhadap beban gempa menjadi penting. Pada umumnya, perencanaan struktur gedung terhadap beban gempa dilakukan dengan metode desain berbasis gaya yaitu analisis statik ekuivalen dan analisis dinamik (analisis respons spektrum dan analisis riwayat waktu). Untuk metode desain berbasis gaya, prosedur analisisnya tercantum dalam SNI 1726 : 2012. Kemudian berkembang trend terbaru untuk perencanaan bangunan tahan gempa yaitu metode desain berbasis kinerja. Untuk desain berbasis kinerja yaitu dengan menentukan tingkat kinerja sebagai acuan dasar perencanaan bangunan tahan gempa. Salah satu cara untuk melakukan desain berbasis kinerja yaitu dengan metode Direct Displacement Based Design (DDBD) yaitu dengan menekankan nilai perpindahan sebagai acuan untuk menentukan kekuatan yang diperlukan bangunan terhadap gempa desain. Kemudian untuk memverifikasi tingkat kinerja yang diinginkan, akan dilakukan analisis pushover terhadap hasil desain dengan DDBD. Biasanya digunakan $A T C-40$, FEMA 356, dan FEMA 440 sebagai peraturan untuk menentukan tingkat kinerja.

\section{Tujuan}

Tujuan dari penelitian ini adalah untuk menentukan tingkat kinerja yang didesain berdasarkan asumsi awal dan mengetahui nilai parameter respons struktur. 


\section{Batasan Masalah}

Batasan masalah pada penelitian ini adalah analisis struktur dilakukan dengan program ETABS v9.7.2, dibuat struktur yang beraturan, gedung perkantoran sepuluh lantai dengan struktur beton bertulang, bangunan terletak di Kota Jakarta dengan jenis tanah lunak (SE), beban yang ditinjau adalah beban gravitasi dan beban gempa, desian balok dan kolom pada satu lantai diambil gaya pada balok dan kolom tengah, tidak dilakukan penulangan geser, pengaruh torsi diabaikan, tidak dilakukan perhitungan struktur bawah, sistem struktur merupakan SRPMK, tidak memperhitungkan pengaruh gempa vertikal, dan metode untuk penentuan beban gempa yaitu $D D B D$.

\section{TINJAUAN PUSTAKA}

\section{Metode Direct Displacement Based Design}

Konsep perencanaan struktur berbasis perpindahan (direct displacement based design) dengan metode Priestley [Priestley, 2007] menggunakan langkah-langkah sebagai berikut :

1. Menentukan tingkat kinerja struktur

Tabel 1 Batasan Simpangan pada Tingkat Kinerja Struktur Sumber : ATC-40, 1996

\begin{tabular}{ccccc} 
Batas & \multicolumn{4}{c}{ Tingkat Kinerja Struktur } \\
\cline { 2 - 5 } $\begin{array}{c}\text { Simpangan } \\
\text { Antar }\end{array}$ & Immediate & Damage & Life & Structural \\
Tingkat & Occupancy & Control & Safety & Stability \\
$\begin{array}{c}\text { Simpangan } \\
\text { Total }\end{array}$ & 0,01 & $0,01-0,02$ & 0,02 & $0,33 \mathrm{~V}_{\mathrm{i}} / \mathrm{P}_{\mathrm{i}}$ \\
$\begin{array}{c}\text { Maksimum } \\
\text { Simpangan } \\
\text { Inelastik }\end{array}$ & 0,005 & $0,005-0,015$ & $\begin{array}{c}\text { Tidak } \\
\text { ada }\end{array}$ & $\begin{array}{c}\text { Tidak } \\
\text { ada } \\
\text { Maksimum }\end{array}$ \\
\hline
\end{tabular}

2. Menghitung gaya geser dasar desain yang secara umum diilustrasikan pada Gambar 1 .
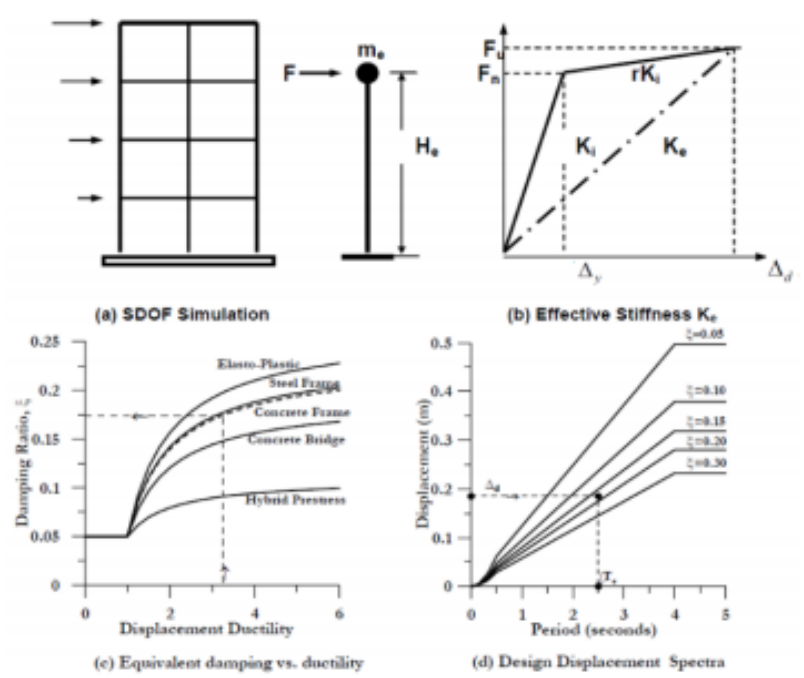

Gambar 1 Konsep Direct Displacement Based Design Sumber : Priestley et.al 2007 : 64

Gambar 1(a) menunjukkan pemodelan gedung sebagai suatu sistem Single Degree of Freedom(SDOF), dengan tinggi bangunan efektif $\left(\mathrm{H}_{\mathrm{e}}\right)$ dan massa efektif $\left(\mathrm{m}_{\mathrm{e}}\right)$. Gambar 1(b) menunjukkan menunjukkan hubungan gaya dan perpindahan yang menunjukkan adanya kekakuan awal elastis $\left(\mathrm{K}_{\mathrm{i}}\right)$ kemudian diikuti oleh kekakuan plastis $\left(\mathrm{rK}_{\mathrm{i}}\right)$. Gaya geser dasar desain metode $D D B D$ menggunakan kekakuan efektif untuk suatu perpindahan rencana $\left(\Delta_{\mathrm{d}}\right)$. Gambar 1(c) menunjukkan redaman efektif ekuivalen yang dihitung berdasarkan redaman elastik awal dan nilai displacement ductility dari suatu sistem struktur. Gambar 1(d) menunjukkan untuk mendapatkan periode efektif $\left(\mathrm{T}_{\mathrm{e}}\right)$, 
yang didapat dari plot antara perpindahan rencana $\left(\Delta_{\mathrm{d}}\right)$ dan respons gempa pada saat redaman inelastik yang telah diubah ke dalam format spektra perpindahan.

\section{Kinerja Struktur}

Kinerja struktur merupakan tingkatan perilaku suatu struktur terhadap gempa rencana. Pada umumnya, tingkat kinerja struktur dapat ditentukan sesuai dengan ketentuan yang tercantum pada ATC-40, FEMA 356, dan FEMA 440.

1. Kinerja menurut $A T C-40$

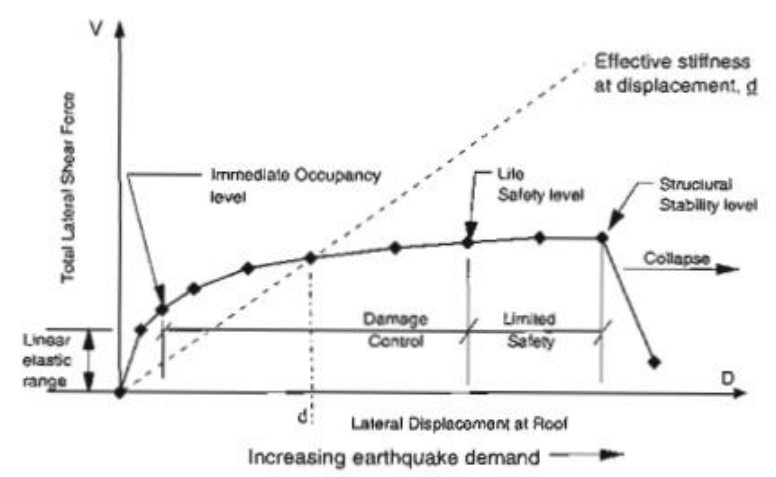

Gambar 2 Tipikal Kurva Kapasitas Pada Berbagai Tingkat Kinerja Sumber : ATC-40, $1996: 6-6$

Gambar 2 menunjukkan beberapa tingkatan kinerja, dimana tingkatan kinerja digambarkan kurva hubungan antara perpindahan lateral dan besar gaya yang bekerja. Simbol "»" menunjukkan tingkat kinerja pada suatu struktur. Dalam metode ini digunakan metode spektrum kapasitas dengan memplotkan demand spektra dan kurva kapasitas sehingga didapatkan tingkat kinerjanya atau dapat dilihat pada Gambar 3.

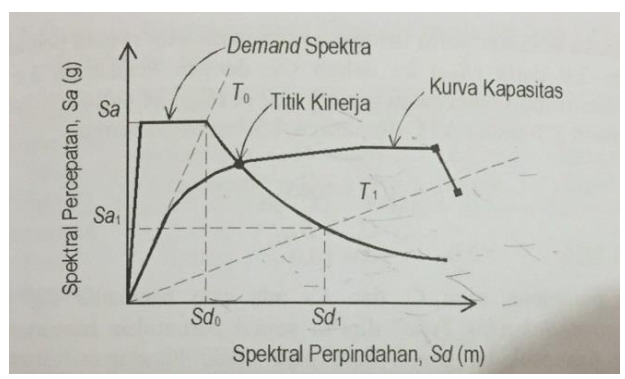

Gambar 3 Plot antara Demand Spektra dan Kurva Kapasitas Sumber : Tavio dan Wijaya, 2018

\section{Kinerja menurut FEMA 356}

Secara garis besar, tingkat kinerjan pada FEMA 356 sama dengan tingkat kinerja pada ATC-40. Berdasarkan FEMA 356 maka kinerja struktur saat terjadi gempa dibagi menjadi beberapa kategori dan dapat dilihat pada Gambar 4 .

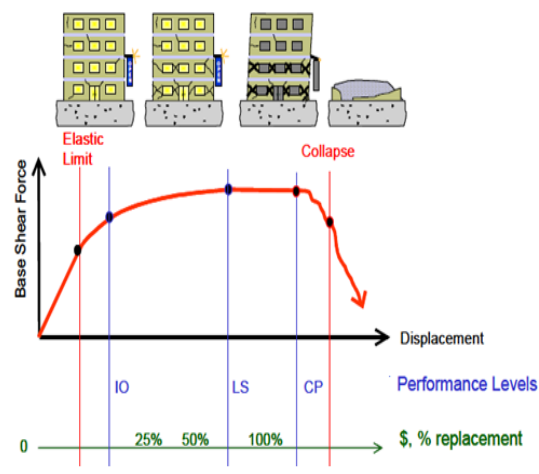

Gambar 4 Tingkat Kinerja Struktur Sumber : FEMA 356 
Dalam metode ini, metode yang digunakan merupakan suatu pendekatan untuk menentukan tingkat kinerja dari struktur disebut dengan dengan metode target perpindahan $\left(\delta_{\mathrm{T}}\right)$. Prosedur penyelesaiannya dilakukan dengan cara memodifikasi respons elastik dari sistem SDOF ekuivalen dengan faktor koefisien $\mathrm{C}_{0}, \mathrm{C}_{1}, \mathrm{C}_{2}$, dan $\mathrm{C}_{3}$.

$$
\delta_{T}=C_{0} C_{1} C_{2} C_{2} S_{\alpha^{2}} \frac{T_{\frac{2}{2}}^{2}}{4 \pi^{2}} \mathrm{~g}
$$

Keterangan :

$\mathrm{T}_{\mathrm{e}}=$ waktu getar efektif

$\mathrm{g}=$ percepatan gravitasi $9,81 \mathrm{~m} /$ detik $^{2}$

$\delta_{\mathrm{T}}=$ target perpindahan

$\mathrm{C}_{0}=$ faktor modifikasi untuk perpindahan spektral menjadi perpindahan atap/puncak

$\mathrm{C}_{1}=$ faktor modifikasi untuk menghubungkan perpindahan inelastik dengan perpindahan respons elastik linier

$\mathrm{C}_{2}=$ faktor modifikasi yang mewakili efek dari bentuk histerestik perpindahan maksimum

$\mathrm{C}_{3}=$ koefisien untuk memperhitungkan pembesaran lateral akibat efek P-Delta

\section{Tingkat Kinerja Menurut FEMA 440}

Metode FEMA 440 merupakan pengembangan dari metode koefisien perpindahan FEMA 356 atau biasa juga disebut metode perpindahan yang diperbaiki. Secara garis besar dasar dalam perhitungan FEMA 440 ini sama dengan FEMA 356, yaitu dengan hasil akhir menentukan target perpindahan $\left(\delta_{\mathrm{T}}\right)$. Perbaikan diberikan untuk menentukan parameter $\mathrm{C}_{1}$ dan $\mathrm{C}_{2}$.

\section{METODE PENELITIAN}

Langkah pertama yang dilakukan dalam penelitian ini adalah dengan melakukan studi literatur tentang perencanaan struktur berbasis kinerja. Kemudian dilakukan modelisasi struktur yang akan dianalisis dengan membuat denah, tinggi struktur, dimensi elemen struktur, dan juga beban yang akan bekerja. Setelah itu dilakukan perhitungan beban gempa dengan metode $D D B D$ sehingga didapat gaya geser dasar desain dan beban gempa didistribusikan ketiap tingkat. Lalu dilakukan perhitungan kebutuhan tulangan longitudinal untuk balok dan kolom untuk di-input ke program ETABS. Dengan demikian didapatkan model struktur aktual untuk dilakukan verifikasi tingkat kinerjanya apakah sesuai dengan desain awal atau tidak. Denah struktur dibuat tipikal dan terlihat seperti pada Gambar 5. Langkah-langkah pengerjaan secara umum dapat dilihat pada Gambar 6.

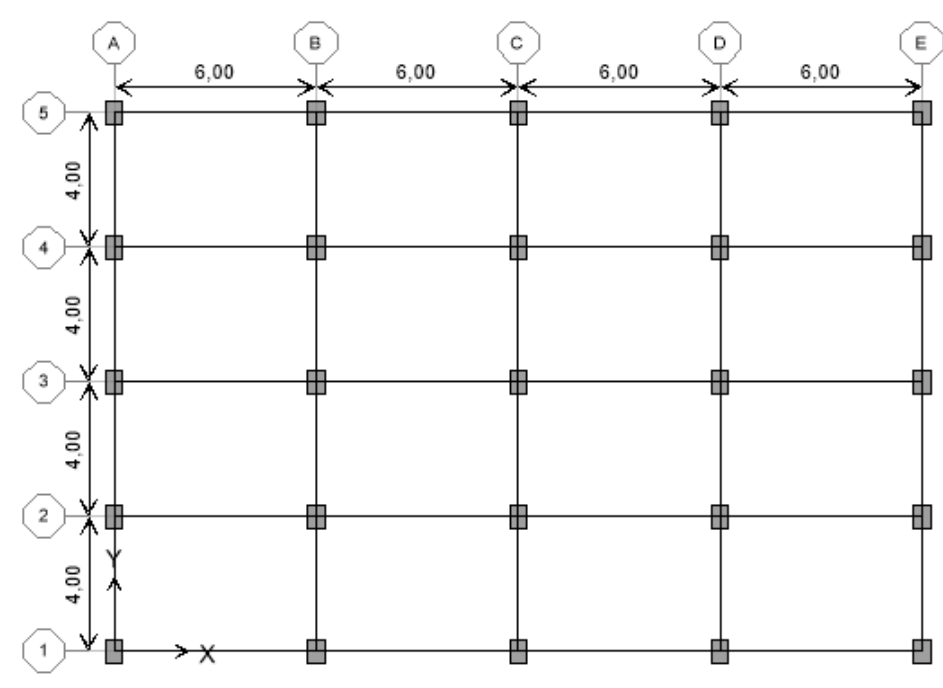

Gambar 5 Denah Struktur Rencana 
Jurnal Mitra Teknik Sipil

Vol. 1, No. 1, Agustus 2018: hlm 139-148

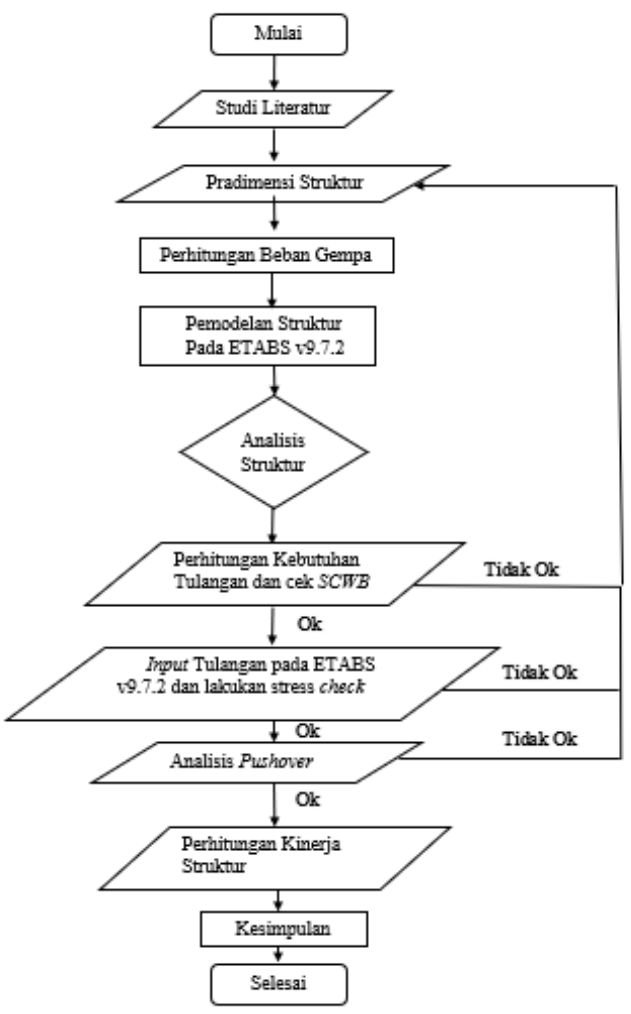

Gambar 6 Diagram Alir

\section{HASIL DAN PEMBAHASAN}

\section{Evaluasi Tingkat Kinerja}

Evaluasi tingkat kinerja struktur digunakan untuk menentukan tingkat kinerja struktur yang didesain. Dari hasil evaluasi kinerja struktur ini nantinya akan didapatkan nilai kinerja struktur berdasarkan ATC-40, FEMA 356 dan FEMA 440. Nilai kinerja struktur hasil yang didesain akan dibandingkan dengan kinerja struktur yang didesain di awal saat perhitungan $D D B D$.

1. Metode Kapasitas Spektrum (ATC-40)

Penentuan tingkat kinerja dengan metode ini sudah built-in dalam program ETABS, sehingga hanya perlu mengkonversi parameter gempa ke dalam $\mathrm{C}_{\mathrm{a}}$ dan $\mathrm{C}_{\mathrm{v}}$ serta menentukan Structural Behavior Type. Untuk hasil tingkat kinerja dengan metode kapasitas spektrum dapat dilihat pada Gambar 7 dan Gambar 8.

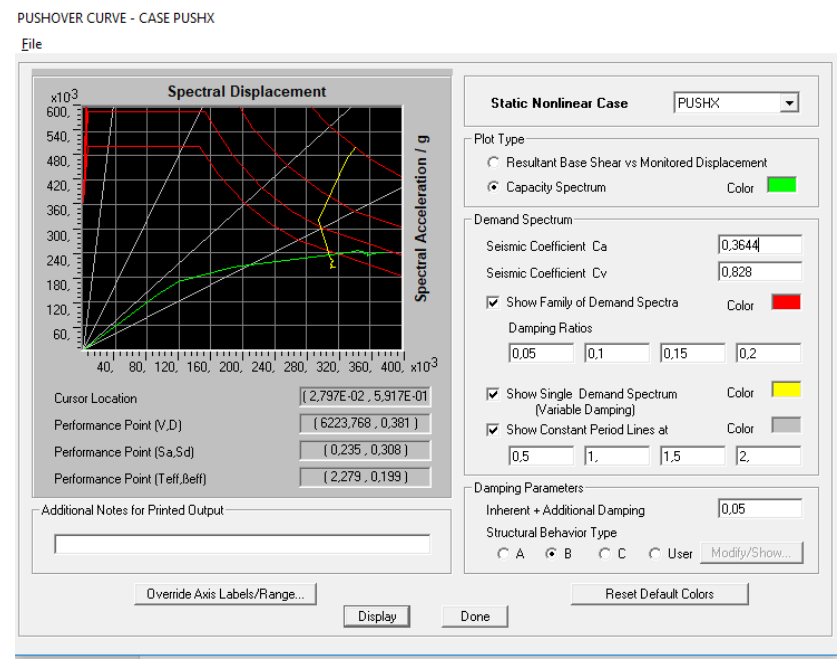

Gambar 7 Spektrum Kapasitas Arah X-X 


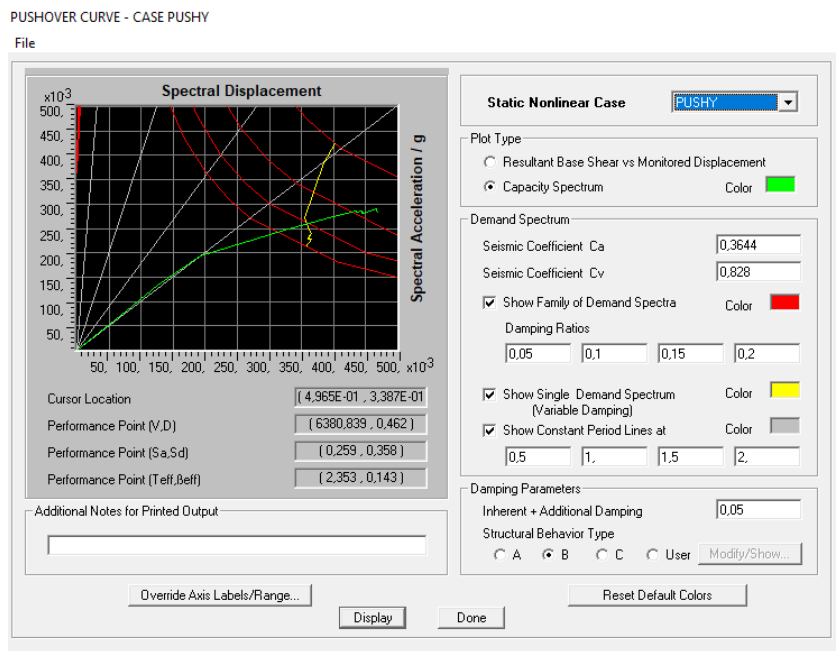

Gambar 8 Spektrum Kapasitas Arah Y-Y

\section{Metode Target Perpindahan (FEMA 356)}

Pada metode ini dilakukan dengan membuat kurva idealisasi biliniear yang diambil dari kurva kapasitas yang dapat dilihat pada Gambar 9 dan Gambar 10.

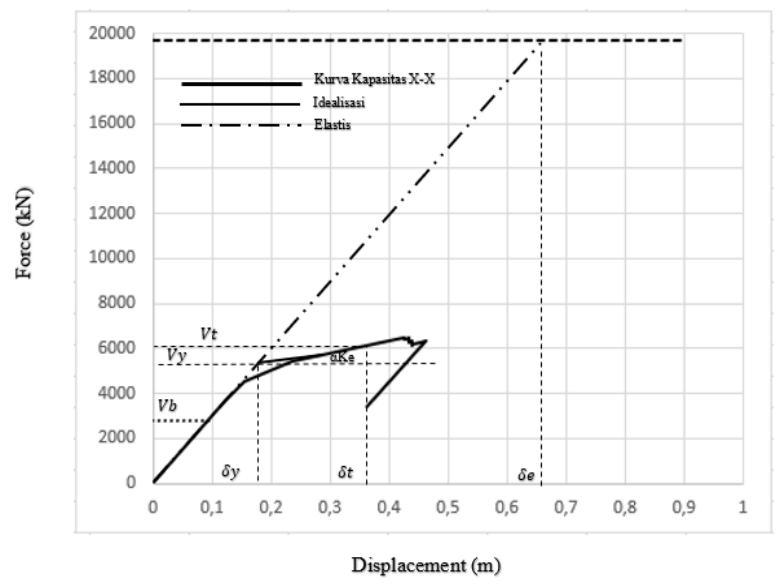

Gambar 9 Kurva Biliniear Pushover Arah X-X

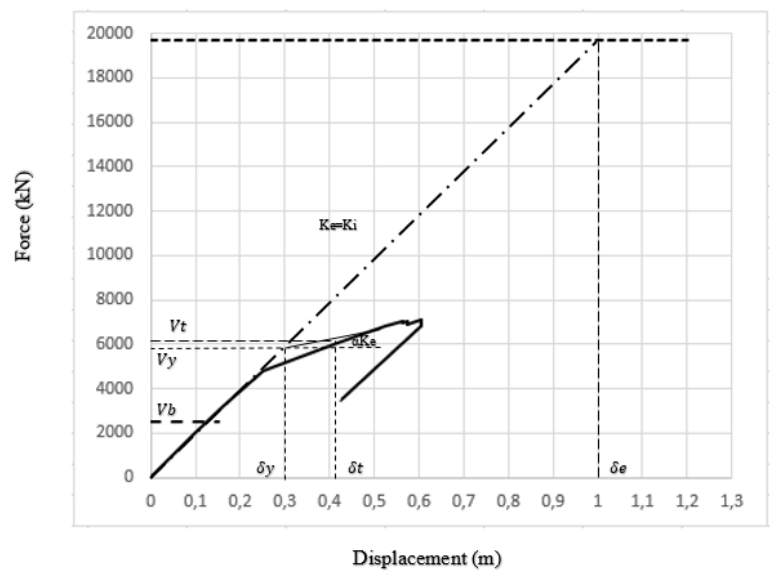

Gambar 10 Kurva Biliniear Pushover Arah Y-Y 
Jurnal Mitra Teknik Sipil

Vol. 1, No. 1, Agustus 2018: hlm 139-148

3. Metode Target Perpindahan yang Diperbaiki (FEMA 440)

Nilai faktor modifikasi $\mathrm{C}_{1}$ dan $\mathrm{C}_{2}$ pada analisis ini sama, sehingga hasil tingkat kinerja FEMA 440 sama dengan hasil tingkat kinerja pada FEMA 356.

\section{Resume}

Dari hasil perhitungan dengan 3 metode di atas, dapat ditabelkan target perpindahan atau nilai performance point untuk masing-masing metode dengan nilai target kinerjanya, dan dapat dilihat pada Tabel 2.

Tabel 2 Performance Point

\begin{tabular}{|c|c|c|c|c|c|}
\hline \multirow{2}{*}{ Arah } & \multirow{2}{*}{ Parameter } & & \multicolumn{3}{|c|}{ Hasil analisis pushover } \\
\hline & & $D D B D$ & ATC -40 & FEMA 356 & FEMA 440 \\
\hline \multirow{5}{*}{$\operatorname{arah} \mathrm{x}-\mathrm{x}$} & target perpindahan, & 0,3929 & 0,381 & 0,36679 & 0,36679 \\
\hline & $\delta_{\mathrm{t}}(\mathrm{m})$ & & & & \\
\hline & Drift aktual $\left(\delta_{t} / \mathrm{T}_{\text {tot }}\right)$ & & 0,01058333 & 0,010188611 & 0,0101886 \\
\hline & Level Kinerja & Life Safety & Damage & Damage & Damage \\
\hline & & & Control & Control & Control \\
\hline \multirow{5}{*}{$\operatorname{arah} y-y$} & target perpindahan, & 0,3929 & 0,462 & 0,4131 & 0,4131 \\
\hline & $\delta_{\mathrm{t}}(\mathrm{m})$ & & & & \\
\hline & Drift aktual $\left(\delta_{t} / T_{\text {tot }}\right)$ & & 0,01283333 & 0,011475 & 0,011475 \\
\hline & Level Kinerja & Life Safety & Damage & Damage & Damage \\
\hline & & & Control & Control & Control \\
\hline
\end{tabular}

Dari Tabel 2 di atas dapat dilihat untuk masing-masing arah pada 3 metode menghasilkan nilai target perpindahan yang hampir mendekati nilai target perpindahan rencana dengan $D D B D$. Hal ini berarti secara keseluruhan struktur berada pada tingkat kinerja kategori Damage Control. Dengan level kinerja desain Life Safety maka struktur belum mencapai tingkat kinerja desain tetapi mendekati nilai kinerja desain.

5. Perbandingan nilai displacement dan drift

Dalam pembahasan ini displacement dan drift aktual hasil analisis pushover digunakan untuk mengetahui perilaku akhir dari struktur yang didesain dan dapat dilihat pada Gambar 11dan Gambar 12.

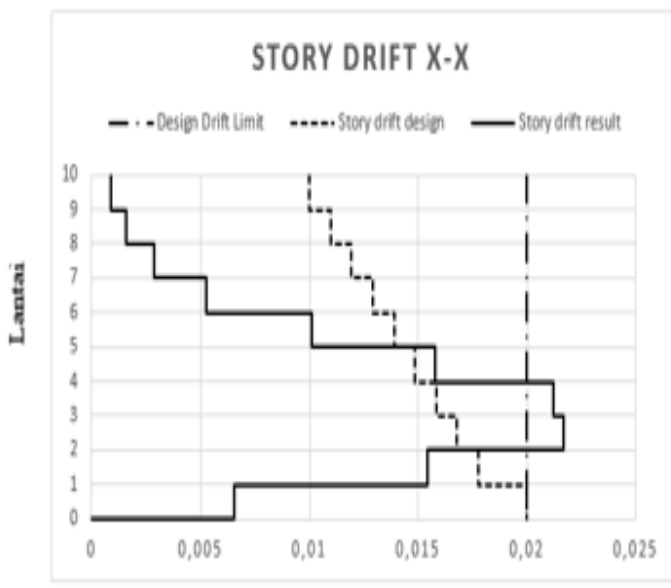

Drift

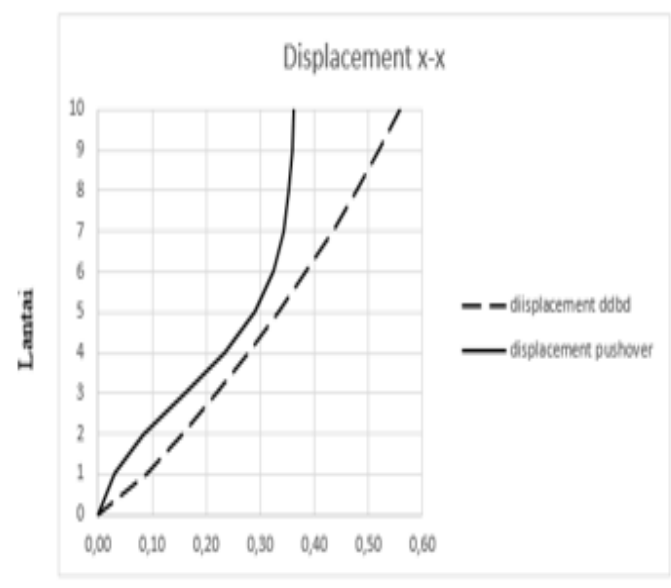

Displacement (m)

Gambar 11 Perbandingan Drift dan Displacement Arah X-X 


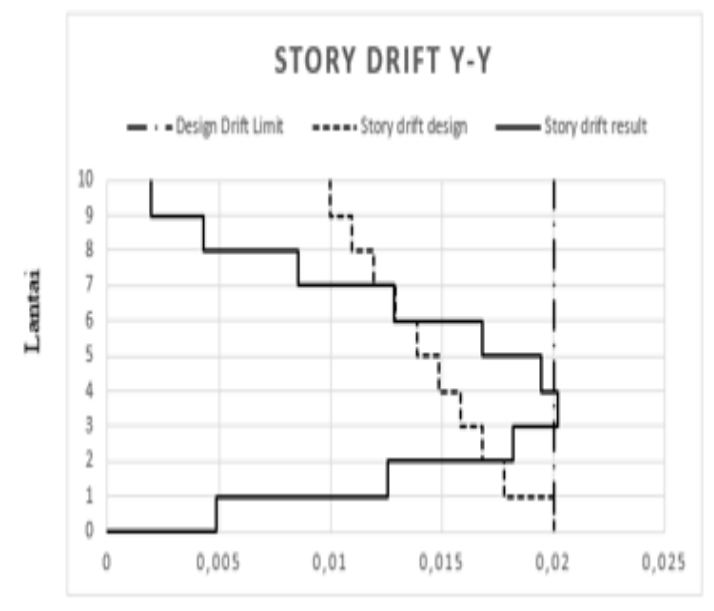

Drift

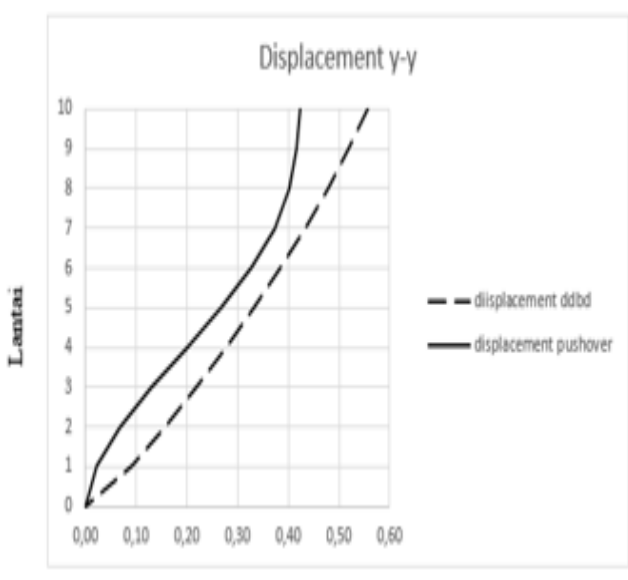

Displacement (m)

Gambar 12 Perbadingan Displacement dan Drift Arah Y-Y

Dari Gambar 11 dan Gambar 12 di atas, dapat diketahui bahwa drift ratio hasil pushover ada yang melebihi nilai Design Drift Limit yang berarti tingkat kinerja melebihi batas Life Safety, sedangkan sebagian besar drift ratio tidak melebihi Design Drift Limit. Untuk nilai displacement hasil analisis pushover dan dengan rencana DDBD memiliki nilai yang hampir mendekati, tetapi mulai lantai 6 sampai 10 displacement hasil pushover menunjukkan nilai yang lebih kecil.

6. Idealisasi Respons Struktur Terhadap SNI $1726: 2012$

Dalam pembahasan ini akan dilakukan idealisasi kurva kapasitas dari hasil pushover analysis untuk mengetahui parameter-parameter respons struktur. Akan dilakukan idealisasi dengan pendekatan secara gaya dan kurva sesuai Gambar 12 dan Gambar 13.

\section{Respons Struktur $\mathrm{x}-\mathrm{x}$}

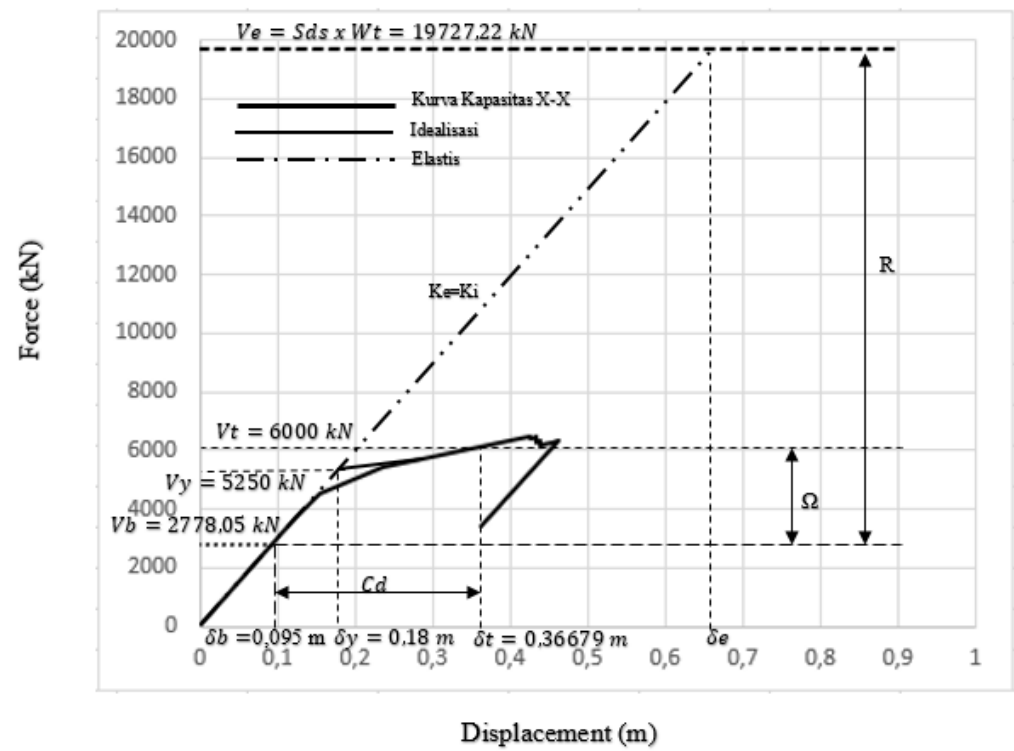

Gambar 13 Respons Struktur Arah X-X 


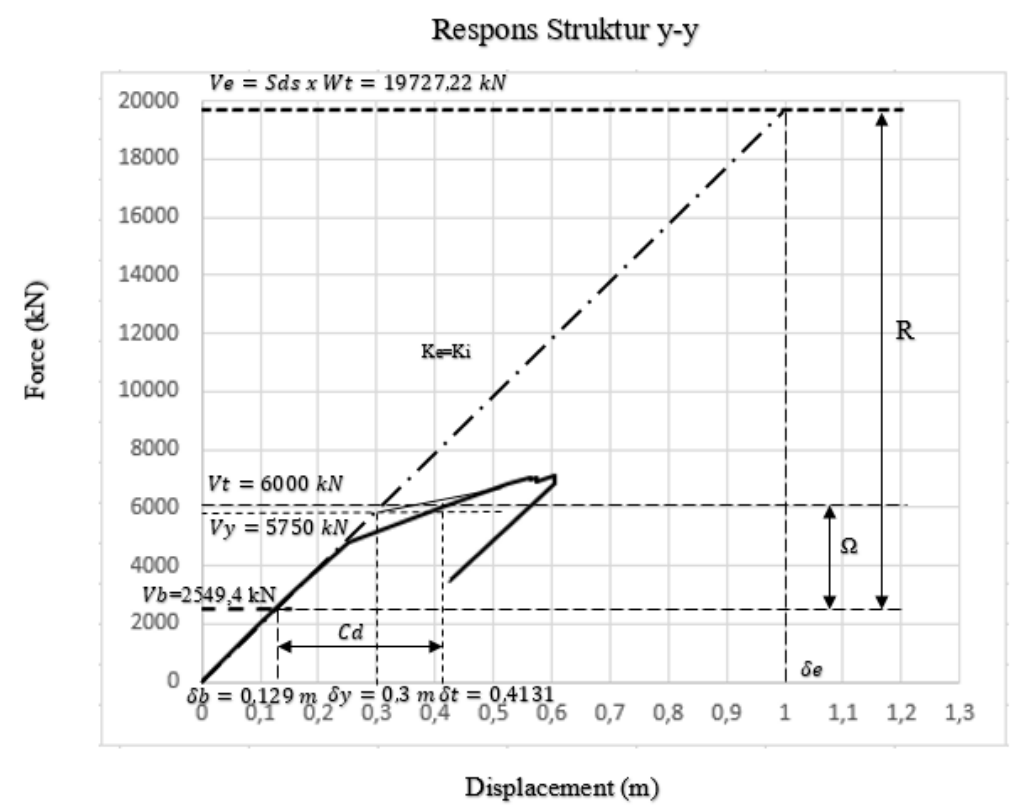

Gambar 14 Respons Struktur Arah Y-Y

Dari Gambar 13 dan Gambar 14 maka didapatkan parameter-paramter respons struktur yaitu, faktor reduksi $R$, faktor pembesaran defleksi, $C_{d}$, dan faktor kuat lebih $\Omega$. Parameter-parameter tersebut akan dibandingkan dengan tabel yang tertera dalam SNI 1726 : 2012 untuk masing-masing arah pada Tabel 3.

Tabel 3 Perbadingan Parameter Respons Struktur

\begin{tabular}{ccccc}
\hline \multirow{2}{*}{ Parameter } & \multicolumn{2}{c}{ Sistem Rangka(x-x) } & \multicolumn{2}{c}{ Sistem Rangka(y-y) } \\
& DDBD & SNI 2012 & DDBD & SNI 2012 \\
\hline $\mathrm{C}_{\mathrm{d}}$ & 3,86 & 5,5 & 3,20 & 5,5 \\
$\Omega$ & 2,16 & 3 & 2,35 & 3 \\
$R$ & 7,10 & 8 & 7,74 & 8 \\
\hline
\end{tabular}

Dari Tabel 3 dapat dilihat bahwa parameter respons struktur hasil $D D B D$ berbeda dengan nilai yang tercantum pada SNI 1726 : 2012, tetapi nilai-nilai tersebut hampir mendekati. Dengan demikian desain struktur berbasis kinerja dengan metode $D D B D$ dapat menjadi alternatif ingin mengetahui performa struktur pada tingkat kinerjanya.

\section{KESIMPULAN}

Berdasarkan hasil pembahasan dapat disimpulkan bahwa :

1. Tingkat kinerja menurut ATC-40,FEMA 356, dan FEMA 440 bahwa struktur berada pada tingkat kinerja Damage Control. Artinya bangunan masih mampu menahan gempa yang terjadi, risiko korban jiwa manusia sangat kecil. Tingkat kinerja yang terjadi belum mencapai desain awal yaitu Life Safety.

2. Nilai displacement yang didapat secara umum dapat dikatakan mendekati desain awal, tetapi mulai lantai 6-10 menunjukkan nilai displacement yang jauh lebih kecil.

3. Nilai drift yang didapat secara umum dapat dikatakan mendekati desain awal, tetapi pada lantai 2, 3, dan 4 nilai drift yang terjadi sedikit melebihi design drift limit atau drift desain awal.

4. Nilai parameter-parameter respons struktur hasil desain dengan $D D B D$ lebih kecil daripada nilai parameter yang tercantum pada SNI $1726: 2012$. 
5. Desain struktur gedung berbasis kinerja dengan metode $D D B D$ akan menjadi suatu alternatif yang bisa digunakan jika ingin mengetahui performa struktur pada taraf kinerjanya.

\section{SARAN}

1. Untuk mengetahui keakuratan metode $D D B D$ yang lebih baik, dapat dilakukan perbandingan dengan Time History Analysis baik liniear maupun nonliniear.

2. Dapat dicoba untuk variasi ketinggian struktur dan juga sistem penahan gaya gempa.

3. Memperhitungkan pengaruh gempa vertikal.

\section{DAFTAR PUSTAKA}

Agus S. 2016. “Perancangan Struktur Beton Bertulang (Berdasarkan SNI 2847:2013)”. Jakarta: Erlangga.

ASCE 7-10. 2010. "Minimum Design Loads for Buildings and Other Structures," Virginia: American Society of Civil Engineers.

ATC-40. 1996. "Seimis Evaluation and Retrofit of Concrete Buildings".Vol. 1. California: Applied Technology Council.

Badan Standarisasi Nasional. 2002. "Tata Cara Perencanaan Ketahanan Gempa untuk Bangunan Gedung (SNI 031726-2002)". Jakarta: BSN.

Badan Standarisasi Nasional. 2012. "Tata Cara Perencanaan Ketahanan Gempa untuk Struktur Bangunan Gedung dan non Gedung (SNI 1726:2012)". Jakarta: BSN.

Badan Standarisasi Nasional. 2013. "Persyaratan Beton Struktural untuk Perancangan Bangunan Gedung dan Struktur (SNI 2847:2013)". Jakarta: BSN.

Budiono, dan Supriatna. 2011. "Studi Komparasi Desain Bangunan Tahan Gempa dengan menggunakan SNI 31726-2002 dan RSNI 03-1726-201X”. Bandung: ITB.

Computer and Structures, Inc. 1999. “Etabs User's Manual-Three-Dimensional Analysis and Design of Building System". First Edition. California: Computers and Structure, Inc.

FEMA 356. 2000. "Prestandard and Commentary for the Seismic Rehabilitation of Building". Washington, D.C.: Federal Emergency Management Agency.

FEMA 440. 2005. "Improvement of Nonliniear Static Seismic Analysis Procedures". Washinton, D.C.: Federal Emergency Management Agency.

Ghosh and Fanella. 2003. "Seismic and Wind Design of Concrete Buildings". USA: International Code Council., INC.

Paulay, T.; dan Priestley, M. J. N; 1992. "Seimic Design of Reinforced Concrete and Masonry Buildings". Newyork: John Wiley \& Sons, Inc.

Priestley, M. J. N; Calvi, G. M.; dan Kowalsky, M. J.; 2007. "Displacement-Based Seimic Deisgn of Structures". Pavia: IUSS Press.

Tavio dan Wijaya. 2018. "Desain Rekayasa Gempa Berbasis Kinerja”. Yogyakarta: ANDI.

Untario, Edward. 2017. "Perbandingan Analisis Statik Dan Dinamik Pada Struktur Dengan Variasi Ketidakberaturan Massa Berdasarkan SNI 03-1726-2012”. Skripsi. Jakarta: Untar.

Widodo P. 2012. “Seismologi Teknik dan Rekayasa Kegempaan”. Yogyakarta: Pustaka Belajar.

Widodo P. 2017. “Analisis Dinamik Struktur”. Yogyakarta: Pustaka Belajar. 